\title{
Introduction to the Research on the Special Marketing Ability of Higher Vocational Automobile Industry under the Background of the Integration of Production and Education
}

\author{
Leijie Gong, Lin Wang \\ Department of Automotive Engineering, Zhejiang Vocational College of Science and Trade, Jinhua, China \\ Email: 810835511@qq.com, 2903883409@qq.com
}

\begin{abstract}
How to cite this paper: Gong, L.J. and Wang, L. (2021) Introduction to the Research on the Special Marketing Ability of Higher Vocational Automobile Industry under the Background of the Integration of Production and Education. Open Access Library Journal, 8: e7039.

https://doi.org/10.4236/oalib.1107039
\end{abstract}

Received: November 25, 2020

Accepted: March 15, 2021

Published: March 18, 2021

Copyright $\odot 2021$ by author(s) and Open Access Library Inc.

This work is licensed under the Creative Commons Attribution International License (CC BY 4.0).

http://creativecommons.org/licenses/by/4.0/

\begin{abstract}
The integration of industry and education is a general idea put forward according to the development of the Times and the demand of the society for teaching reform. In order to study the daily life of higher vocational students, the immune ability of health teaching under the influence of various risk factors, the general education, the promotion of self-management and the integration of the automobile industry are all studied. In this study, "the integrated education mode of industry and education" is integrated into the curriculum system of general education in higher vocational colleges, so as to provide the curriculum plan of competitive elements of practical training in automobile industry for the teaching of general education in higher vocational colleges. At the same time, one-way analysis of variance and T-test, collection of maternity leave integrated education on the emotional state and positive/negative emotions of vocational students satisfaction.
\end{abstract}

\section{Subject Areas \\ Education \\ Keywords \\ Integration of Production and Education, Automobile Marketing, School Attributes, Characteristic}

\section{Introduction}

China's auto consumption scale increasing, the automobile market scale is con- 
stantly expanding, The implementation of the production-education integrated teaching system follows certain principles, and the core principle is to let students learn how to learn, rather than just make students learn a certain knowledge point. Teachers are transformed from "single type" to "action-oriented", while students are transformed from the traditional passive accepting mode to the mode of giving play to their subjective initiative and combining theory with practice. Teaching activities are transformed from traditional classroom teaching mode to theoretical teaching mode and practical teaching mode in factories and workshops. The teaching means are changed from traditional blackboard writing to multimedia, information technology and network teaching. The teaching concept needs to reverse the traditional bad teaching concepts such as "emphasizing teaching method, ignoring learning method", "emphasizing deduction, ignoring induction", "emphasizing teaching, ignoring operation", "emphasizing description, ignoring intuition", "emphasizing knowledge, ignoring practice", "emphasizing single skill, ignoring comprehensive ability" and so on.

Currently rapid development of automobile industry, the requirement of higher vocational education also should keep pace with the Times. Mechanics professional training mode of the implementation of the comprehensive marketing can not only make the society transport more skillful, operation ability of specialized talents enough strong, but also provide talents conveying for the continuous development of automobile industry in our country, so as to effectively promote the automobile maintenance industry and the continuous development of auto industry.

The integration of production and education is under the guidance of the concept of the integration of truth and reality in the whole process of automobile operation teaching [1]. Focusing on students' daily life and daily life in school, we pay attention to all kinds of risk factors and errors affecting teaching health, and advocate self-health management in teaching, which pursues not only individual physical health of students, but also complete health in spirit, psychology, physiology, society, environment, morality and other aspects. In foreign countries, especially in Germany and the United States, vocational education has developed earlier and has formed a relatively mature theoretical system of vocational education and has rich practical experience in the integration of industry and education [2].

\section{Research Methods and Objects}

\subsection{Research Methods}

Research to higher vocational education in higher vocational colleges clear existing mechanics problems of talent cultivation, and on this basis, the analysis of influence factors of higher vocational education to mechanics teaching model to provide the corresponding strategies of talent cultivation, and for other higher vocational technical schools in terms of mechanics major, Integrated marketing mechanics teaching mode innovation, combination of keyword search, query the relevant papers and books, combined with own under- 
standing on the study and summary, and the basic idea of perfect after literature review of research.

Questionnaire survey to the related group, the basic situation of the current automobile industry, the basic demand of higher people mechanics, higher vocational school teaching, students' basic situation, the motor repair specialty basic teaching status quo of the research, the most effective information.

Study was compiled by self 1 ) The modification of the subjective report questionnaire of emotion composed by the emotional state scale (POMS) and the Positive/negative Emotion scale (PANAS) and the test of its reliability and validity [3]; 2) Design of skill evaluation standard; it is concluded that the students' skills and emotional experience associated with the degree of master data, promote elective courses students have good "emotional experience", produce good psychological benefits, promote the formation of marketing skills, and even form good practice consciousness.

Current rapid development of automobile industry, the requirement of higher vocational technology school vocational education also should keep pace with The Times, mechanics professional training mode of the implementation of the comprehensive marketing can not only for the society transport more skillful, operation ability strong enough specialized talents, but also provide talents conveying for the continuous development of automobile industry in our country, so as to effectively promote the automobile maintenance industry and the continuous development of auto industry.

\subsection{Research Objects}

This study mainly studies the influence of "industry-education integrated education mode" on marketing skills and "emotional experience" of college students majoring in automobile industry. It takes the students majoring in automobile industry of Zhejiang Vocational and Technical College as experimental examples.

\section{Research Methods and Objects}

\subsection{Different Job Attributes Give Play to the Psychological Benefits of Students Majoring in Automobile Industry}

Car professional training model is integrated marketing based on national standard, the cultivation of the teaching goal is to promote students' comprehensive professional quality and level, take the student as this, through in the actual work tasks, task and content into the teaching content, integrating theory with practice, training and jobs. The implementation of comprehensive marketing training mode in the whole teaching process has obvious characteristics, which is quite different from the traditional teaching mode in higher vocational colleges. Integrated marketing training camp mainly refers to the integration of theory, practice, combined with the mode of teaching mode, and the "task driven" teaching, project oriented teaching model is very similar, is actually stick 
to the actual practical give priority to the basic principle in the career, to the actual work process for the teaching guide, based on the students' professional skills training as the core teaching and thus the theoretical teaching and practical work skills to realize the combination of effective.

On the whole, in terms of advanced educational concepts, domestic scholars' research results on "school-enterprise cooperation" are in the majority, while the research on "production-education integration" fails to highlight the unique characteristics of "production-education integration" educational concepts. In view of the current situation and trend of the development of the automobile industry [4], the daily life of automobile industry skills and the diversification of automobile industry activities have become the inevitable requirements for the professional development of automobile industry in modern society. In schools, too, the demand for cars is no longer a traditional professor. Professional technology has diversified changes in life style, and the demand of students majoring in automobile industry tends to be more diversified.

The basic concept of "fusion education education model", is to arrange teaching cycle into full season, "skills week", "week" skills including the exercise period, the preseason, formal game, the final game, will be the start of the course the students into different groups and a role, in the course of competitions as the main activity form, middle school students between partners teaching, situational teaching, cooperative learning, team work, role playing and fair competition, and so on, promote the course of organic, to shape students into professional passion and have ability, have automobile camp with automobile literacy.

Give students good professional emotional experience, promote the formation of automobile marketing skills, develop students' social adaptability, and consolidate their consciousness and habits of lifelong automobile marketing are functions that should be taken into consideration by the development of automobile marketing courses in colleges and universities at the present stage. As the most popular automobile teaching major in China, automobile marketing is widely popular among college students. How to give full play to the psychological benefits of automobile marketing projects on the basis of their original popularity, so as to form a good sense of automobile marketing skills for students' future development.

\subsection{Different Course Attributes Can Give Full Play to the Psychological Benefits of Students Majoring in Automobile Industry}

As an important part of the training system of college majors, the course of automobile marketing plays an important role in promoting the physical and mental health development of students [5]. For most of the students, the teaching in universities of automobile industry is a bridge from the relatively closed school environment to the more complex social environment, and also the final "fortress" of students' physical and mental development. This study hopes that the "industry-education integrated education model" will be integrated into the 
curriculum system of general education. In higher vocational colleges, so as to provide the curriculum plan of competition elements for general education teaching in higher vocational colleges, and meanwhile provide experimental data and theoretical basis for future research on emotional state and positive/negative emotions.

Deepening the teaching reform of colleges in the process of teaching can not only add simple teaching methods, and also needs to be based on the characteristics of project characteristics and teaching object, according to the corresponding teaching mode of carries on the reasonable planning of the whole process of teaching, at the same time into the reasonable teaching method for teaching the process of feedback and control [6]. At the same time, it also puts forward new challenges and requirements for automobile teaching itself and automobile teachers in universities.

1) Strong practicality. Automobile professional training mode integrated marketing method in the application of car major, through the actual operating environment that real and effective to improve their practical ability, to the training mode of comprehensive marketing make the theoretical knowledge and practical skills for promotion.

2) More technical. Based on practical ability training and guided by hands-on practice ability training, the comprehensive marketing training mode of automobile major gives consideration to theoretical knowledge learning and practical ability training, so as to improve students' specialized teaching training and professional technical operation ability.

3) Higher teaching efficiency and quality. A teaching mode in which theory guides practice and practice deepens theory. Students do and learn in school, thus effectively improving the teaching quality and teaching efficiency of the whole automobile repair major.

\section{Conclusions}

1) It fits the actual teaching situation of the major of automobile industry, and makes clear the content and goal of the research subject.

In the actual teaching situation, multi-dimensional evaluation and individual cognitive differences mean that students should be guided to give full play to their imagination on the basis of good professional knowledge. Therefore, it is also necessary to improve students' moral quality through the setting of moral teaching objectives and the development of teaching activities according to students' own differences.

2) Based on the students' teaching needs, teaching strategies are put forward in line with the practical needs.

The quality of teaching is more demanding. Car professional training mode integrated marketing is to let students understand the theory and practice in parallel way of teaching, then the request for the teacher's ability and basic quality is higher, including the basic professional theory knowledge, practice ability, 
basic professional ethics accomplishment, the skills of using modern teaching methods and teaching tools.

The hardware is more demanding. The comprehensive marketing training mode of the automobile industry is driven by the working mode of the actual profession and dominated by the completion of practical work tasks. Therefore, corresponding teaching facilities are needed in the teaching process. Especially for automobile repair major, it is more necessary to have the corresponding plant, equipment, tools and other teaching equipments to support teachers to complete the whole process of comprehensive marketing training mode of automobile operation major. If necessary, specific teaching strategies can be established through multiple discussions of research groups to ensure the feasibility and rationality of teaching strategies.

\section{Conflicts of Interest}

The authors declare no conflicts of interest regarding the publication of this paper.

\section{References}

[1] Qu, T. (2007) Series on Bus Brand Construction (6): Bus Brand Marketing Methodology. Commercial Vehicle, No. 10, 42-43.

http://qikan.cqvip.com/Qikan/Article/Detail?id=25566490

[2] Guo, G.J. (2019) Promoting Huang Yanpei's Vocational Education Thought and Promoting the High-Quality Development of Vocational Education and on the trend of the Previous Huang Yanpei Vocational Education Awards. Education and Careers, 937, 27-33.

[3] Li, X.X. and Li, D. (2020) Association between Physical Activity and Emotion among Adolescents during coVID-19 At Home. Journal of Beijing Sport University, No. 3, 84-91.

[4] Shao, Y.Q. (2018) Research on the "Internet +" Based Auto Maintenance Chain Development Mode.

[5] Zhang, Y. (2017) On the Benefits of School Yoga Teaching to Students' Physical and Mental Development. Chinese Journal of Education, No. S1, 165-166.

[6] Wu, F.S. (2019) Research on Intellectual Property Education Model in Higher Vocational Colleges. Journal of Ezhou University, 26, 72-75. 